Non-Sternotomy Approaches to Left Ventricular Assist Device Placement: Combined Left Subcostal - Right MiniThoracotomy Technique-Anelechi Anyanwu. Expected publication December 2014.

\section{EVOLVING TECHNOLOGY AND BASIC SCIENCE Seminars:}

State of the Art: The Promise and Challenges of Cardiac Stem Cell Therapy-Richard Weisel. Semin Thorac Cardiovasc Surg. 2014 Spring; 26(1):44-52.

\section{CARDIOTHORACIC EDUCATION AND TRAINING Seminars:}

News and Views: Integrated Surgical Residency Initiative: Implications For Cardiothoracic Surgery-John Ikonomidis and Editorial Commentary-Ara Vaporciyan. Semin Thorac Cardiovasc Surg. 2014 Spring; 26(1):14-26.

Discussion in Cardiothoracic Treatment and Care: Manpower-Richard Shemin, David Fullerton, John Ikonomidis, John Mayer, Cameron Wright. Expected publication December 2014.

\section{The AATS Graham Foundation}

\section{In Its 41st Year, the AATS Graham Foundation Announces New Specialty Programs}

Over the past year, new fellowship programs for international professionals, fellows, residents, and medical students have been developed that provide specialized educational and training opportunities.

The Cardiothoracic Surgical Investigator Program caters to cardiothoracic surgeons interested in conducting clinical or translational research, while the Traveling Scholar Program provides young cardiothoracic surgeons from around the world a chance to study clinical techniques at a secondary institution.

Our new Resident Poster Session Scholarship for thoracic surgical residents has become extremely popular and competitive, along with the Critical Care Scholarship program that boasts over 50 students expected to participate in 2014!

The AATS Graham Foundation Fellowship for Advanced EBUS Training Program (sponsored by Olympus America) provides an educational experience for young thoracic surgeons from North America to spend a focused period of between one month and four months' time studying clinical techniques at a host institution proficient in EBUS. The AATS Graham Foundation Intuitive Surgical Robotics Fellowship provided an advanced educational experience for 8 North American general thoracic Fellows and their attending surgeons to spend a two-day period at Intuitive Surgical's Atlanta, GA, facility to experience an introductory training course on Intuitive Surgical's da Vinci System.

The Honoring our Mentors Fellowship program, initially honoring F. Griffith Pearson, enables North American surgeons who have recently completed their residency in general thoracic surgery to spend a focused period of four (4) to six (6) weeks' time studying clinical techniques at a host institution in North America.

Since our parent Association, the AATS, underwrites all operational costs of the Foundation, $100 \%$ of all individuals' contributions to go directly to Foundation programming. The AATS Graham Research Foundation is driving leadership, learning, and innovation in the pursuit of excellence!

For more information on the AATS Graham Foundation, please visit http://aatsgrahamfoundation.org.

\title{
The Western Thoracic Surgical Association
}

\section{WTSA 41st Annual Meeting}

Save the Date!

June 24-27, 2015

Fairmont Chateau Whistler

Whistler, British Columbia, Canada

\section{Applications for Membership}

The WTSA is now accepting Applications for Membership online for Active as well as Candidate membership status.
Visit the WTSA Web site at www.westernthoracic.org to read the complete membership eligibility requirements and to initiate an online application.

\section{Active Member}

$\$ 325.00$ annually, plus $\$ 50.00$ initiation fee

Applicant must meet all membership criteria, including but not limited to:

- Reside within or have completed a cardiothoracic residency training program within the geographic limits of the Association.

- Have been engaged in the practice of thoracic and cardiovascular surgery for at least three years 
following completion of postgraduate training. If a candidate completed his/her thoracic surgical residency in an institution within the geographic limits of the Association, such completion may count towards one of the three years of practice.

- Have a full and unrestricted license to practice medicine in his or her respective state or province, and have a current appointment on the surgical staff of a hospital with no reportable action pending that could adversely affect such applicant's staff privileges at any hospital.

\section{Candidate Member}

$\$ 100.00$ annually

Applicant must meet all membership criteria, including but not limited to:

- Be matched or enrolled in either a cardiothoracic surgery education program accredited by the Residency Review Committee for Thoracic Surgery under the authority of the ACGME or a program approved for cardiothoracic surgery education by the Royal College of Surgeons of Canada-or their equivalency-from within the Association's geographic limits. Individuals who have completed their education in one of the above programs and are in the process of acquiring certification in cardiothoracic surgery by either the American Board of Thoracic Surgery or the Royal College of Surgeons of Canada also are eligible to apply for Candidate membership. Individuals who trained outside the Association's geographic limits who are now residing within the Association's boundaries but do not yet have three years in practice also are eligible to apply for Candidate membership.

An application must include the following uploads: a photo, a complete curriculum vitae with bibliography, and, for Active applicants, his/her 3 most significant articles. The application must be completed and submitted online by March 1, 2015, and all support letter(s) (three for Active applicants, one for Candidates) uploaded by that applicant's sponsor(s) by March 31, 2015, in order for the applicant to be considered for election to membership at the 2015 Annual Meeting.

\section{The American Board of Thoracic Surgery}

\section{Notices}

The part I (written) examination will be held on Monday, November 14, 2014, at multiple sites throughout the United States using an electronic format. The closing date for registration is August 15, 2014. Those wishing to be considered for examination must apply online at www.abts.org.

To be admissible for the Part II (oral) examination, a candidate must have successfully completed the Part I (written) examination.

A candidate applying for admission to the certifying examination must fulfill all the requirements of the Board in force at the time the application is received. Please address all communications to the American Board of Thoracic Surgery, 633 North St Clair Street, Suite 2320, Chicago, IL 60611 (telephone: 312-202-5900).

\section{Requirements for Maintenance of Certification}

Diplomates of the American Board of Thoracic Surgery (ABTS) who plan to participate in the Maintenance of Certification (MOC) process as Certified-Active must hold an unrestricted medical license in the locale of their practice and privileges in a hospital accredited by the JCAHO (or other organization recognized by the ABTS). In addition, a valid ABTS certificate is an absolute requirement for entrance into the Maintenance of Certification process. If your certificate has expired, the only pathway for renewal of a certificate is to take and pass the Part I (written) and the Part II (oral) certifying examinations. The names of individuals who have not maintained their certificate will no longer be published in the American Board of Medical Specialties Directories. Diplomates' names will be published upon successful completion of the Maintenance of Certification process.

The CME requirements are 150 Category I credits earned over a 5-year period. At least half of these CME hours need to be in the broad area of thoracic surgery. Category II credits are not accepted. Interested individuals should refer to the Board's Web site (www.abts.org) for a complete description of acceptable CME credits. Diplomates will be expected to submit verification of $\mathrm{CME}$ earned.

Diplomates in the Maintenance of Certification process will need to provide a summary of their major cases performed during the year prior to application. The practice review should not exceed 100 cases.

Diplomates in the Maintenance of Certification process will be required to complete all sections of the SESATS selfassessment examination. It is not necessary for Diplomates to purchase SESATS individually, because it will be sent to them after their application has been approved.

Diplomates may apply for Maintenance of Certification in the year their certificate expires, or if they wish to do so, they may apply up to two years before it expires. However, the new certificate will be dated 10 years from the date of expiration of their original certificate or most recent recertification certificate. In other words, going through the 